\title{
DEVELOPMENT STRATEGY OF NATURAL TOURISM IN PANCAR MOUNTAIN NATURAL PARK
}

\author{
Arde Lindung Pambudi \\ Arief Daryanto \\ Sri Hartoyo \\ Business Management Post Graduate Program Institut Pertanian Bogor \\ Raya Pajajaran Street, Bogor 16143 \\ Email: arde.pambudi@gmail.com
}

\begin{abstract}
The purposes of this study are to identify the internal and external factors and to determine the best strategy for developing natural tourism in Pancar Mountain Natural Park. This study employs a descriptive method through surveys using a purposive sampling method. The analysis tools used are IFE and EFE, IE Matrix, SWOT Matrix and QSPM. Recommended strategies are: 1) product development strategy, 2) market penetration, 3) optimizing the cooperation of stakeholders, 4) defining the area and boundary of Pancar Mountain Natural Park, 5) increasing citizen participation and 6) increasing the role of associations.
\end{abstract}

Keywords: Natural Tourism, Development Strategy, QSPM

\begin{abstract}
Abstrak
Penelitian ini bertujuan untuk mengidentifikasi faktor-faktor internal dan eksternal dan menentukan prioritas strategi dalam pengembangan pariwisata alam di Taman Wisata Alam Gunung Pancar. Penelitian ini menggunakan metode deskriptif melalui survei yang dipilih secara sengaja. Alat analisis yang digunakan adalah IFE dan EFE, matriks IE, matriks SWOT dan QSPM. Ada enam rekomendasi strategi: 1) menetapkan strategi pengembangan produk, 2) menetapkan strategi penetrasi pasar, 3) mengoptimalkan kerjasama stakeholder, 4) memperjelas luas dan batas Taman Wisata Alam Gunung Pancar, 5) meningkatkan peran serta masyarakat dan 6) meningkatkan peran asosiasi.
\end{abstract}

Kata Kunci: Pariwisata Alam, Pengembangan Strategi, QSPM

\section{INTRODUCTION}

The General Directorate for Natural Conservation and Forest Protection (PHKA) (2003) stated that natural travels were voluntary and temporary travels to enjoy the beauty and unique phenomena of nature in national parks, forest parks or natural parks, while natural tourism constituted everything that related to natural travel including natural tourism industry and other enterprises in that field.

Indonesian tourism prospers fairly well. This fact is affirmed by the raise of Indonesian Tourism rank from $81^{\text {st }}$ of 133 member countries in year 2009 to $74^{\text {th }}$ of 139 member countries in year 2011 (WEF, 2011). This ranking was determined according to Travel \& Tourism Competitiveness Index (TTCI). The index shows the measurements of factors and policies that influence the development of tourism in different countries. In year 2010 tourism contributed US\$7.604 million to Indonesia's foreign exchange and ranked $4^{\text {th }}$ in the list of foreign exchange con- tributors, and in year 2011 tourism contributed US\$8.500 million. The contribution of foreign exchange through tourism has been raising steadily since year 2006. This can be seen in the following Table 1.

Table 1. The Rank of Tourism in Foreign Exchange Contribution

\begin{tabular}{ccc}
\hline Year & Rank & Value (US\$ million) \\
\hline 2006 & 6 & 4.448 \\
2007 & 5 & 5.346 \\
2008 & 4 & 7.377 \\
2009 & 3 & 6.298 \\
2010 & 4 & 7.604 \\
2011 & 3 & 8.500 \\
\hline
\end{tabular}

Source: Kemenparekraf, 2012.

World Economic Forum (2011) stated that the measurement of competitiveness and growth of a country's travel and tourism is done in accordance with Travel \& Tourism Competitiveness Index 
(TTCI) which refers to three main categories, namely: (1) T\&T Regulatory Framework which includes aspects that relate to government policies and regulations; (2) T\&T Business Environment and Infrastructure which includes aspects from business environment and economics infrastructure; (3) $T \& T H u-$ man, Cultural and Natural Resources which includes the people, the culture and the natural resources of a country.

Pancar Mountain Natural Park is a tourism destination area which is also a forest park. The site is in the supervision of Balai Besar Konservasi Sumber Daya Alam (the Governmental Body of Natural Resources Conservation) Region I of West Java Province. In promoting the benefits of natural parks which includes natural beauties and extraordinary natural phenomena for tourism and recreational purposes, the government can hand over the management of natural tourism to citizens by issuing Izin Pemanfaatan Pariwisata Alam (Permission to make use of natural parks).

The management of natural tourism can be handled by cooperative unions, state owned enterprises, private or individual enterprises. In order to make use of natural biological resources dan their ecosystems continuingly, especially in tourism destination areas, and in the effort to develop environment-friendly tourism and to advance community's welfare, the Ministry of Forestry has issued a decree No. 54/Kpts-II/93 dated February $8^{\text {th }}, 1993$ which gave the authority to manage Pancar Mountain Natural Park to PT Wana Wisata Indah in the form of Izin Pemanfaatan Pariwisata Alam (Permission to make use of natural parks).

The management of Pancar Mountain Natural Park by PT Wana Wisata Indah which refers to the
Work Plan of Natural Tourism Development is considered not optimal since the establishment of facilities which should have finished by 2007 is still in construction now, with the consequent that the target of 65,754 visitors a year and $20 \%$ raise in Non-Tax National Revenue (PNBP) cannot be realized.

Table 3 presents the increase of the number of tourists to Bogor Regency and the potential number of tourists to Pancar Mountain Natural Park. The potential number of tourists in 2007 was 742,282, in 2008: $1,844,855$, in 2009: $2,169,299$, in 2010: 2,163,503, and in 2011: 2,623,293. Pancar Mountain Natural Park is one among 42 tourist destinations in Bogor Regency.

Based on these backgrounds, this research aimed to: (1) analyze the internal and external factors that influence the development of natural tourism in Pancar Mountain Natural Park, (2) formulate alternatives of development strategy for Pancar Mountain Natural Park, (3) recommend strategies that can be applied in developing natural tourism in Pancar Mountain Natural Park.

\section{THEORETICAL BASIS AND FRAMEWORK}

Strategic Management is defined as an art and a science of formulating, implementing, and evaluating cross-functional decisions which enable an organization to achieve its goals. The purpose of strategic management is to create and to make use of new and different opportunities for the organization's future (David, 2011). Strategic management is a concept that is related to time and involves a continuing process, which aims to achieve the organization's goals in harmony with its environmental situation. Thus strategic management can be employed to identify

Table 2. The Growth Rate of Non-Tax National Revenue of Pancar Mountain Natural Park

\begin{tabular}{lrrrrrr}
\hline & \multicolumn{6}{c}{ Year } \\
\cline { 2 - 7 } & \multicolumn{1}{c}{$\mathbf{2 0 0 7}$} & $\mathbf{2 0 0 8}$ & $\mathbf{2 0 0 9}$ & $\mathbf{2 0 1 0}$ & $\mathbf{2 0 1 1}$ & $\mathbf{2 0 1 2}$ \\
\hline Visitors & 6,825 & 7,710 & 9,592 & 10,476 & 43,000 & 45,954 \\
Non-Tax National Revenue & $13,650,000$ & $17,994,000$ & $19,184,000$ & $21,108,000$ & $86,936,000$ & $97,446,000$ \\
Growth of Non-Tax & & $32 \%$ & $7 \%$ & $10 \%$ & $312 \%$ & $12 \%$
\end{tabular}

National Revenue

Source: The General Directorate for Natural Conservation and Forest Protection (Ditjen PHKA), 2013

Table 3. The Potential Number of Tourists to Pancar Mountain Natural Park

\begin{tabular}{lrrrrr}
\hline \multicolumn{1}{c}{ Type of Visit } & \multicolumn{5}{c}{ Year } \\
\cline { 2 - 6 } & \multicolumn{1}{c}{$\mathbf{2 0 0 7}$} & $\mathbf{2 0 0 8}$ & $\mathbf{2 0 0 9}$ & \multicolumn{1}{c}{$\mathbf{2 0 1 0}$} & $\mathbf{2 0 1 1}$ \\
\hline Bogor Regency & 746,527 & $1,851,680$ & $2,179,961$ & $2,173,937$ & $2,666,293$ \\
Pancar Mountain Natural Park & 6,825 & 7,710 & 9,592 & 10,476 & 43,000 \\
Potential & 742,282 & $1,844,855$ & $2,169,299$ & $2,163,503$ & $2,623,293$ \\
\hline
\end{tabular}

Sources: Statistics Central Bureau (BPS), 2011 and The General Directorate for Natural Conservation and Forest Protection (Ditjen PHKA), 2013. 
promising activities, which focuses on resources, including natural resources, human resources, and man-made resources, for favorable long term development (Hubeis \& Najib, 2008).

The process of strategic management, according to David (2011), consists of three main phases, namely formulating the strategy, implementing the strategy, and evaluating the strategy. Formulating the strategy includes developing organization's vision and mission, indentifying opportunities and threats from outside the organization, finding out the strengths and weaknesses inside the organization, determining organization's long term goals, creating alternative strategies and selecting the most appropriate strategies. Implementing strategy in an organization requires formation of yearly goals, planning policies, motivating employees, allocating resources in order to realize the strategies that have been formulated. Implementing strategy includes promoting culture that supports stra- tegy, establishing effective organization structure, directing marketing steps, planning budgets, developing and employing information system, and connecting employees' compensations with organization performance. Implementing strategy is also considered as the acting phase of strategic management. This means that implementing strategy causes employees and managers to cooperate in realizing the strategies that have been formulated.

Natural travel is travelling or part of travelling which is done voluntarily and temporarily with the purpose of enjoying the beauty and the unique phenomena of nature in national parks, forest parks, or natural parks, while natural tourism constitutes everything that relates to natural travel including natural tourism industry and other enterprises in that field (General Directorate for Natural Conservation and Forest Protection/Ditjen PHKA, 2003). Natural Tourism enterprise relates to activities of organizing means

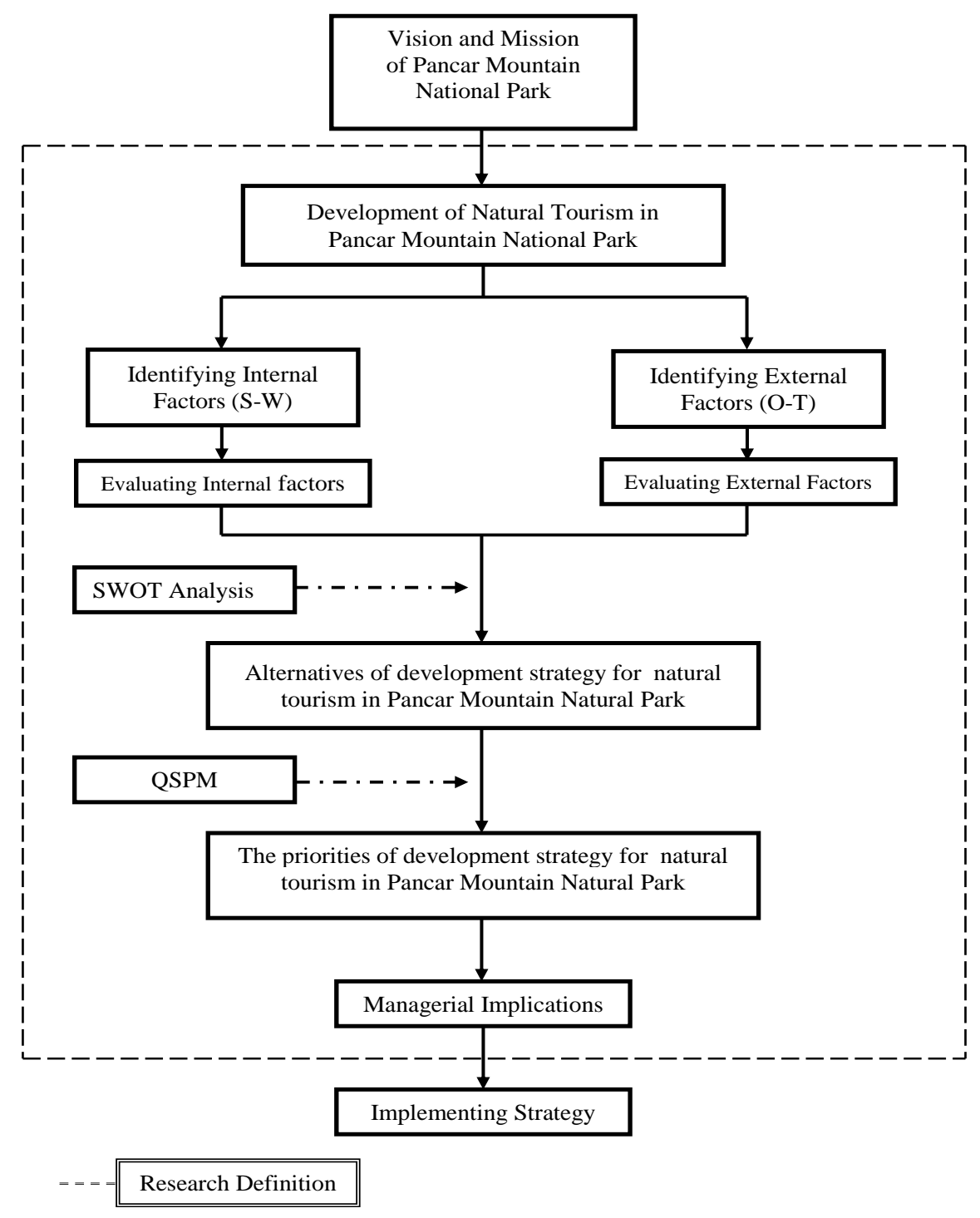

Figure 1. The Framework of Conceptual Thinking 
of travel and tourism in the area of national parks, forest parks, or natural parks based on planned management.

The development plan is general and relates to the development of national parks, forest parks, and natural parks which has been issued by the Ministry of Forestry. Natural tourism product is a natural travel object or service that can be offered in order to attract people (tourists) so that they want to own, enjoy, or consume it to fulfill their desire and satisfaction (General Directorate for Natural Conservation and Forest Protection/Ditjen PHKA)

\section{RESEARCH METHOD}

This research was carried out in Pancar Mountain Natural Park, which is administratively located in Karang Tengah Village, in the District of Citeureup, Bogor Regency, West Java Province. The research was performed for seven months, from August 2012 until February 2013. The researchers used descriptive method to obtain information, explanation, and condition pertaining to the object of research. The data employed in this research was primary and secondary data. Primary data was obtained through questionnaire and in-depth interview, while secondary data was obtained through literature study from various relevant sources.

Table 4. Data Type and Data Source

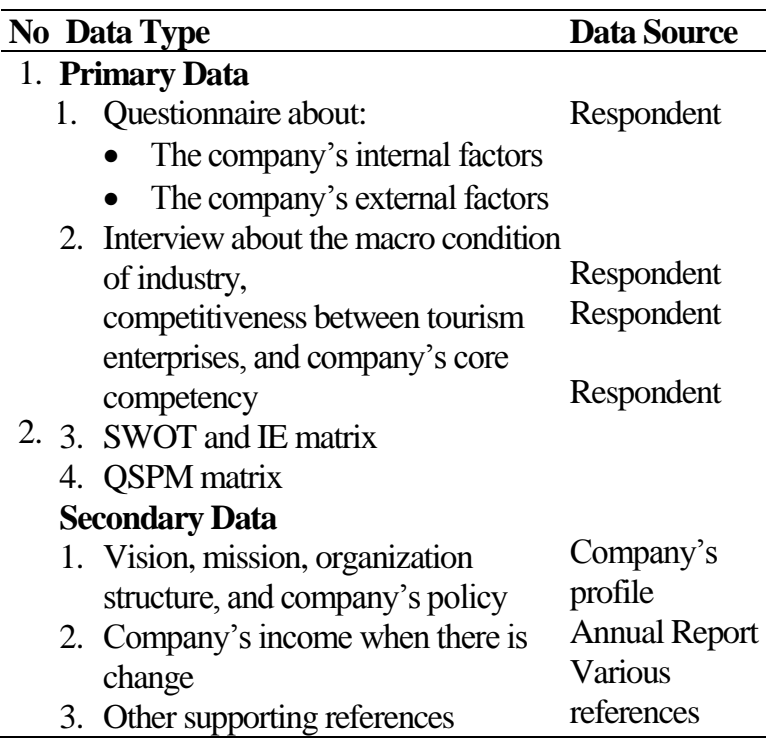

The technique of sample acquirement (through questionnaire) is done purposively (purposive sampling). It is carried out with the consideration that the respondents are skilled and competent in their fields. The respondents consist of seven internal respondents and three external respondents. Internal respondents are from the management of PT Wana Wisata Indah (Wana Wisata Indah Limited Company), Balai Besar KSDA Jawa barat (the Governmental Body of Natural Resources Conservation of West Java), and Ditjen PHKA (General Directorate for Natural Conservation and Forest Protection), while external respondents are from expert staff of the Association of Indonesian Natural Tourism (Asosiasi Pariwisata Alam Indonesia) and Pusat Pengendalian Kehutanan (The Center of Forest Control).

The analysis of internal and external factors will give the internal factor evaluation (IFE), the external factor evaluation (EFE) and the present position of Pancar Mountain Natural Park in the internal external matrix (IE). Internal and external environmental factors which have influence on the company's position in IE matrix are used to determine the SWOT matrix of Pancar Mountain Natural Park. Then the alternatives of strategies that result from SWOT matrix are used to determine the priorities of development strategies by employing QSPM analysis.

External Factor Evaluation Matrix (EFE Matrix) is a tool of strategy formulation which is used to evaluate factors outside the company. This matrix helps strategy makers of the company to summarize and analyse information concerning economy, social and cultural situation, demography, environment, politics, government, law, technology, and business competition.

SWOT (Strengths Weaknesses Opportunities Threats) analysis is part of the development of organization's strategy. SW constitute the internal analysis while OT constitute the external analysis of the organization. The strategy that is based on internal analysis is called inside-out strategy, while the strategy that is based on external analysis is called outside-in strategy. Inside-out strategy looks at resources limitations as impediments, while outside-in strategy looks at opportunities as chief appeals. In daily usage, both strategies are combined, so that they are called SWOT analysis or TOWS analysis. SWOT analysis helps to set up fit and match.

TWOS analysis is usually employed by marketing people. The difference of emphasis lies between external factors (OT/TO) and internal factors (SW/WS) (Supratikno et al., 2005), while Hutabarat \& Huseini (2006) stated that TOWS approach proceeded from external environment followed by internal analysis, and started from issues which threaten the organization and need to be taken care of.

QSPM matrix is a technical analysis to determine the relative attractiveness of the implementation of alternative strategies. This technique is employed in the third phase of strategy formulation analysis. QSPM matrix describes the relative advantages of 
Table 5. SWOT Matrix

\begin{tabular}{lll}
\hline IFE & $\begin{array}{l}\text { STRENGTHS (S) } \\
\text { Determine the organization's internal } \\
\text { strengths }\end{array}$ & $\begin{array}{l}\text { WEAKNESSES (W) } \\
\text { Determine the organization's internal } \\
\text { weaknesses }\end{array}$ \\
\hline $\begin{array}{l}\text { OPPORTUNITIES (O) } \\
\begin{array}{l}\text { Determine existing external } \\
\text { opportunities }\end{array}\end{array}$ & $\begin{array}{l}\text { S-O STRATEGY } \\
\text { Create strategies which employ strengths } \\
\text { to utilize opportunities }\end{array}$ & $\begin{array}{l}\text { STRATEGI W-O } \\
\text { Create strategies which minimalize weaknesses } \\
\text { by utilizing opportunities }\end{array}$ \\
\hline $\begin{array}{l}\text { THREATS (T) } \\
\begin{array}{l}\text { Determine existing external } \\
\text { threats }\end{array}\end{array}$ & $\begin{array}{l}\text { S-T STRATEGY } \\
\text { Create strategies which employ strengths } \\
\text { to overcome threats }\end{array}$ & $\begin{array}{l}\text { W-T STRATEGY } \\
\text { Create strategies which minimalize weaknesses } \\
\text { by avoiding threats }\end{array}$ \\
\hline
\end{tabular}

Source: David, 2011.

each strategy which subsequently become the objective foundation for selecting one or several specific strategies for the organization or the company (Umar, 2001).

\section{RESEARCH RESULTS AND DISCUSSIONS}

The internal factors which influence the formation of development strategies for Pancar Mountain Natural Parks consist of strengths factor and weaknesses factor. From interviews with respondents we find that the internal factors which constitute the strengths of the organization are: a) The location of Pancar Mountain Natural Park is strategic; b) Pancar Mountain Natural Park has great attractiveness; c) The implementation of Izin Pemanfaatan Pariwisata Alam (Permission to make use of natural parks); d) Pancar Mountain Natural Park has a legal status as natural park; e) In line with the program of Balai Besar KSDA Jawa Barat (the Governmental Body of Natural Resources Conservation of West Java) to raise Non-Tax National Revenue.

While the internal factors which constitute the weaknesses of the organization are: a) The work plan of natural tourism development is not optimally established; b) The Natural Resources Conservation Office in Bogor does not perform satisfactorily; c) The number and qualifications of human resources are limited; d) Natural tourism marketing or promotion is deficient; e) The division and arrangement of sites in the provision of means and infrastructures for natural tourism is not clearly defined; $f$ ) The types and numbers of means and infrastructures that have been built and that are being prepared do not match the expected number of visitors; $g$ ) The maintenance of means and infrastructures is unsatisfactory; h) Supporting infrastructures are not sufficient.

The external factors which influence the formation of development strategies for Pancar Mountain Natural Park consist of opportunities and threats.
From interviews with respondents we find that the external factors which constitute opportunities for the organization are: a) The availability of means and infrastructures outside Pancar Mountain Natural Park is fairly good; b) The potential number of visitors is high; c) The laws which regulate natural tourism are sufficient; d) There are prospects of employments or establishing enterprises for citizens around Pancar Mountain Natural Park; e) The support from the Association of Indonesian Natural Tourism (Asosiasi Pariwisata Alam Indonesia).

While the factors which constitute the threats against the organization are: a) Disturbance to natural resources by human activities; b) Law enforcement is not maximal; c) The awareness of surrounding citizens about natural conservation is low; d) There is overlapping usage of landsite with citizens around Pancar Mountain Natural Park.

From internal factor evaluation (IFE) we find that the strengths which have the highest scores are the strategic location of Pancar Mountain Natural Park and its legal status as natural park. The weakness which has relatively high score is the unclearly defined division and arrangement of sites in the provision of means and infrastructures for natural tourism. The mean score of internal strategic factors is 2.376 which indicates that the internal policy of the administration of Pancar Mountain Natural Park does well in utilizing the strengths and overcoming the weaknesses.

From external factor evaluation (EFE) we find that the opportunity which has significant score is the high potential number of visitors. The threat which has significant score is the disturbance to natural resources by human activities. The mean score of external strategic factors is 2.239 which indicates that externally, the response of the administration of Pancar Mountain Natural Park to the opportunities and threats they face in establishing development strategy is relatively good. 
Table 6. Analysis of Internal and External Strategic Factors

\begin{tabular}{|c|c|c|c|c|c|}
\hline No. & $\begin{array}{l}\text { EXTERNAL STRATEGIC } \\
\text { FACTORS } \\
\text { OPPORTUNITIES } \\
\end{array}$ & $\begin{array}{l}\text { MEASURED } \\
\text { SCORE }\end{array}$ & No. & $\begin{array}{c}\text { INTERNAL STRATEGIC } \\
\text { FACTORS } \\
\text { STRENGTHS } \\
\end{array}$ & $\begin{array}{l}\text { MEASURED } \\
\text { SCORE }\end{array}$ \\
\hline 1 & $\begin{array}{l}\text { The availability of means and } \\
\text { infrastructures outside Pancar } \\
\text { Mountain Natural Park is fairly good }\end{array}$ & 0.182 & 1 & $\begin{array}{l}\text { The location of Pancar Mountain } \\
\text { Natural Park is strategic }\end{array}$ & 0.347 \\
\hline 2 & The potential number of visitors is high & 0.342 & 2 & $\begin{array}{l}\text { Pancar Mountain Natural Park has } \\
\text { great attractiveness }\end{array}$ & 0.332 \\
\hline 3 & $\begin{array}{l}\text { The laws which regulate natural } \\
\text { tourism are sufficient }\end{array}$ & 0.205 & 3 & $\begin{array}{l}\text { The implementation of IPPA } \\
\text { (Permission to make use of natural } \\
\text { parks) }\end{array}$ & 0.237 \\
\hline 4 & $\begin{array}{l}\text { There are prospects of employments or } \\
\text { establishing enterprises for citizens } \\
\text { around Pancar Mountain Natural Park }\end{array}$ & 0.211 & 4 & Legal status as natural park & 0.347 \\
\hline 5 & $\begin{array}{l}\text { The support from the Association of } \\
\text { Indonesian Natural Tourism (Asosiasi } \\
\text { Pariwisata Alam Indonesia). }\end{array}$ & 0.165 & 5 & $\begin{array}{l}\text { In line with the program of Balai } \\
\text { Besar KSDA Jawa Barat (the } \\
\text { Governmental Body of Natural } \\
\text { Resources Conservation of West } \\
\text { Java) to raise Non-Tax National } \\
\text { Revenue } \\
\text { WEAKNESSES }\end{array}$ & 0.243 \\
\hline 1 & $\begin{array}{l}\text { Disturbance to natural resources by } \\
\text { human activities }\end{array}$ & 0.262 & 1 & $\begin{array}{l}\text { The work plan of natural tourism } \\
\text { development is not optimally } \\
\text { established }\end{array}$ & 0.151 \\
\hline 2 & Law enforcement is not maximal & 0.256 & 2 & $\begin{array}{l}\text { The Natural Resources Conservation } \\
\text { Office in Bogor does not perform } \\
\text { satisfactorily }\end{array}$ & 0.120 \\
\hline 3 & $\begin{array}{l}\text { The awareness of surrounding citizens } \\
\text { about natural conservation is low }\end{array}$ & 0.239 & 3 & $\begin{array}{l}\text { The number and qualifications of } \\
\text { human resources are limited }\end{array}$ & 0.068 \\
\hline 4 & $\begin{array}{l}\text { There is overlapping usage of landsite } \\
\text { with citizens around Pancar Mountain }\end{array}$ & 0.376 & 4 & $\begin{array}{l}\text { Natural tourism marketing or } \\
\text { promotion is deficient }\end{array}$ & 0.139 \\
\hline & & & 5 & $\begin{array}{l}\text { The division and arrangement of sites } \\
\text { in the provision of means and } \\
\text { infrastructures for natural tourism is } \\
\text { not clearly defined }\end{array}$ & 0.081 \\
\hline & & & 6 & $\begin{array}{l}\text { The types and numbers of means and } \\
\text { infrastructures that have been built } \\
\text { and that are being prepared do not } \\
\text { match the expected number of visitors }\end{array}$ & 0.162 \\
\hline & & & 7 & $\begin{array}{l}\text { The maintenance of means and } \\
\text { infrastructures is unsatisfactory }\end{array}$ & 0.069 \\
\hline & & & 8 & $\begin{array}{l}\text { Supporting infrastructures are not } \\
\text { sufficient }\end{array}$ & 0.079 \\
\hline $\begin{array}{l}\text { TOT } \\
\text { FAC }\end{array}$ & $\begin{array}{l}\text { TAL SCORE OF EXTERNAL } \\
\text { STORS } \\
\end{array}$ & 2.239 & \multicolumn{2}{|c|}{$\begin{array}{l}\text { TOTAL SCORE OF INTERNAL } \\
\text { FACTORS }\end{array}$} & 2.376 \\
\hline
\end{tabular}

Based on the internal and external analysis, we can determine the SWOT matrix which gives six strategy alternatives, namely: (1) Product development by developing types of tourism attractions; (2) Increase the role of associations in the management of Pancar Mountain Natural Park; (3) Increase market- ing or promotion through information technology; (4) Optimize the cooperation of all stakeholders in the management of Pancar Mountain Natural Park; (5) Define the site area and boundary of Pancar Mountain Natural Park; (6) Increase the participation of surrounding citizens in cultivating natural tourism. 
Table 7. The Order of Priority of the Development Strategies of Pancar Mountain Natural Park

\begin{tabular}{|c|c|c|}
\hline Order of Priority & Description of Strategy & $\begin{array}{l}\text { sum total attractive score } \\
\text { (STAS) }\end{array}$ \\
\hline Strategy I, S-O (1) & Product development by developing types of tourism attractions & 6.273 \\
\hline Strategy III, W-O (1) & Increase marketing or promotion through information technology & 5.921 \\
\hline Strategy IV, W-O (2) & $\begin{array}{l}\text { Optimize the cooperation of all stakeholders in the management of Pancar } \\
\text { Mountain Natural Park }\end{array}$ & 5.848 \\
\hline Strategy V, S-T & Define the site area and boundary of Pancar Mountain Natural Park & 5.838 \\
\hline Strategy VI, W-T & $\begin{array}{l}\text { Increase the participation of surrounding citizens in cultivating natural } \\
\text { tourism }\end{array}$ & 5.050 \\
\hline Strategy II, S-O (2) & $\begin{array}{l}\text { Increase the role of associations in the management of Pancar Mountain } \\
\text { Natural Park }\end{array}$ & 5.041 \\
\hline
\end{tabular}

From QSPM calculation we find that the highest sum total attractive score (STAS) is achieved by the S-O strategy (1), namely product development by developing types of tourism attractions with the score of 6.273. The second highest STAS is achieved by the W-O strategy (1), namely implement marketing or promotion through information technology with the score of 5.921. The third highest STAS is achieved by the W-O strategy (2), namely optimize the cooperation of all stakeholders in the management of Pancar Mountain Natural Park with the score of 5.848. The fourth rank is hold by the S-T strategy, namely define the site area and boundary of Pancar Mountain Natural Park with the score of 5.838. The fifth rank is hold by the W-T strategy, namely increase the participation of surrounding citizens in cultivating natural tourism with the score of 5.050. And the sixth rank is increasing the role of associations in the management of Pancar Mountain Natural Park with the sum total attractive score of 5.041.

\section{MANAGERIAL IMPLICATIONS}

Development of tourism sector holds a strategic role in regional development, and is expected not to focus only on building the means of natural tourism as has been prevailing so far. Development of tourism is expected to increase the potentials of natural resources and the efforts of natural conservations. One of these undertakings is the development of natural tourism in Pancar Mountain Natural Park.

From the research results, we obtain several strategy alternatives with the order of priority acquired through the help of QSPM approach. The principal strategy is the development of types and quality of tourism attractions. To make the strategy support the program of Balai Besar Konservasi Sumber Daya Alam (the Governmental Body of Natural Resources Conservation), there are managerial implications that should be considered in the efforts to optimize its duties and functions in developing Pancar Mountain Natural Park.
The principal strategy that has been pointed out by the QSPM analysis, namely the development of types and quality of tourism attractions is in line with the scheme of the Work Plan of Natural Tourism Development of PT Wana Wisata Indah for Pancar Mountain Natural Park. However, the scheme has not been carried out yet because at present PT Wana Wisata Indah is focusing on building hot water swimming pool area which should have been finished by year 2007.

This managerial implication is expected to be an input for the management of Pancar Mountain Natural Park. Considering that Environmental Management Plan for the period of 2010-2014 will soon end, we hope this might be taken for consideration in the formulation of the next Environmental Management Plan.

\section{CONCLUSIONS AND SUGGESTIONS}

\section{Conclusions}

There are several conclusions from this research in accordance with the research's goal, namely:

1. There are ten most influential factors in the formation of development strategies for Pancar Mountain Natural Park. The most influential strength factors are: (1) The location of Pancar Mountain Natural Park is strategic; (2) Legal status as natural park; (3) Pancar Mountain Natural Park has great attractiveness. The most influential weakness factors are: (1) The division and arrangement of sites in the provision of means and infrastructures for natural tourism is not clearly defined; (2) The types and numbers of means and infrastructures that have been built and that are being prepared do not match the expected number of visitors; (3) Supporting infrastructures are not sufficient. The most influential opportunity factors are: (1) The potential number of visitors is high; (2) There are prospects of employments or establishing enterprises for citizens around Pancar 
Mountain Natural Park. The most influential threat factors are: (1) Disturbance to natural resources by human activities; (2) Law enforcement is not maximal.

2. There are six alternative strategies obtained from SWOT matrix which are in line with IE matrix, namely (1) Product development by developing types of tourism attractions; (2) Increase the role of associations in the management of Pancar Mountain Natural Park; (3) Increase marketing or promotion through information technology; (4) Optimize the cooperation of all stakeholders in the management of Pancar Mountain Natural Park; (5) Define the site area and boundary of Pancar Mountain Natural Park; (6) Increase the participation of surrounding citizens in cultivating natural tourism.

3. The order of priorities of the development strategies for Pancar Mountain Natural Park obtained from further analysis by QSPM calculation and based on highest score is as follows:

a. Product development by developing types of tourism attractions.

b. Increase marketing or promotion through information technology.

c. Optimize the cooperation of all stakeholders in the management of Gunung Pancar Natural Park.

d. Increase the participation of surrounding citizens in cultivating natural tourism.

f. Increase the role of associations in the management of Pancar Mountain Natural Park

\section{Suggestions}

This research is limited to formulating strategies which can be developed according to existing situation and condition. In order to extend the research, we would like to give the following suggestions:

1. Considering the managerial implications, there should be re-evaluation to ascertain the feasibility of natural tourism enterprise of every holder of IPPA (Permission to make use of natural parks). Managerial implication constitutes an input for research object - in this case Pancar Mountain Natural Park, which results from the present research; while re-evaluation is an input of managerial implication. Thus, tourism enterprises that do not perform well should increase their efforts. If they don't do that, they can be given a penalty or their permission is even cancelled.

2. There should be further research on the analysis of the marketing of natural tourism products to obtain information about the expectations and needs of the visitors of Pancar Mountain Natural Park. This research is expected to give information about the characteristics of ecological tourists.

3. In developing natural tourism there should be a tourism supervision unit in Balai Besar KSDA Jawa Barat Kementerian Kehutanan (the Governmental Body of Natural Resources Conservation of West Java under the Ministry of Forestry), which handles the supervision of Pancar Mountain Natural Park explicitly. The tourism supervision unit is expected to direct tourism development and improve supervision function and protection of biological diversities and their ecosystems.

4. There should be further research on the impact of strategy implementation, by employing quantitative parameter, to obtain deeper analysis result of the implementation of development strategies for Pancar Mountain Natural Park.

\section{REFERENCES}

David, F. R. 2011. Strategic Management: Concepts and Cases. New Jersey: Pearson Education, Inc.

Hubeis, M. \& Najib, M. 2008. Manajemen Strategik dalam Pengembangan Daya Saing Organisasi. Jakarta: PT Elex Media Komputindo.

Hutabarat, J. \& Martani, H. 2006. Proses, Formasi dan Implementasi Manajemen Strategik Kontemporer Operasionalisasi Strategi. Jakarta: PT Elex Media Komputindo.

Kementerian Kehutanan (Kemenhut), Direktorat Jenderal Perlindungan Hutan dan Konservasi Alam \& Direktorat Wisata Alam dan Pemanfaatan Jasa Lingkungan. 2003. Pedoman Rencana Pengembangan Pariwisata Alam Nasional di Kawasan Hutan. Bogor: Kemenhut.

Kementerian Pariwisata dan Ekonomi Kreatif (Kemenparekraf) \& Direktorat Jenderal Pariwisata. 2012. Rangking Devisa Pariwisata Terhadap Komoditas Ekspor Lainnya. Jakarta: Kemenparekraf.

PT Wana Wisata Indah (WWI). 2004. Rencana Karya Pengusahaan Pariwisata Alam PT Wana Wisata Indah. Jakarta: Unpublished.

Supratikno, H., Widjaja, A. W., Sugiharto, \& Durianto, D. 2005. Advanced Strategic Management: Back to Basic Approach. Jakarta: PT Gramedia Pustaka Utama.

Umar, H. 2001. Strategic Management in Action. Jakarta: PT Gramedia Pustaka Utama.

World Economic Forum (WEF). 2011. The Travel \& Tourism Competitiveness Report 2011. Geneva: World Economic Forum. 